\title{
Gallic acid production under anaerobic submerged fermentation by two bacilli strains
}

\author{
Pedro Aguilar-Zárate ${ }^{1}$, Mario A. Cruz ${ }^{2}$, Julio Montañez ${ }^{1}$, Raúl Rodríguez-Herrera', Jorge E. Wong-Paz ${ }^{1}$, \\ Ruth E. Belmares ${ }^{1}$ and Cristóbal N. Aguilar ${ }^{*^{*}}$ (1)
}

\begin{abstract}
Background: Tannase is an enzyme that catalyses the breakdown of ester bonds in gallotannins such as tannic acid. In recent years, the interest on bacterial tannases has increased because of its wide applications. The lactic acid bacteria (LAB) plays an important role in food tannin biotransformation, it has the ability of hydrolyse tannins in ruminants intestine. The finding of tannin hydrolysis by LAB has sparked their use as tannase producer.

Results: The bacterial strains used in the present work were identified as Bacillus subtilis AM1 and Lactobacillus plantarum CIR1. The maximal tannase production levels were 1400 and $1239 \mathrm{U} / \mathrm{L}$ after 32 and $36 \mathrm{~h}$ of fermentation respectively, for $B$. subtilis $A M 1$ and L. plantarum CIR1. Maximum gallic acid release was $24.16 \mathrm{~g} / \mathrm{L}$ for B. subtilis $A M 1$ and $23.73 \mathrm{~g} / \mathrm{L}$ for $L$. plantarum CIR1. HPLC analysis showed the formation of another peaks in the retention time range of 9-14 min, which could be attributed to the formation of di or tri-galloyl glucose.
\end{abstract}

Conclusions: According to database, the strains were identified as Bacillus subtilis AM1 and Lactobacillus plantarum CIR1. In conclusion, both strains had the capability to produce good titres of extracellular tannase and release gallic acid.

Keywords: Tannase, Gallic acid, Bacterial strains, Anaerobic, Submerged fermentation, Liquid chromatography

\section{Background}

Tannase (Tannin-acyl-hydrolase, E.C. 3.1.1.20) is an industrially important microbial enzyme. It catalyses the hydrolysis of ester and depside bonds in hydrolysable tannins such as tannic acid. Tannase is used in the beverage industries to remove chill haze formation in beer and wine $[1,2]$. Additionally, it widely applied to reduce the antinutritional effects of poultry and animal feed along with food detanification and industrial effluent treatment [3-5]. This enzyme is also used in the manufacturing of instant tea and gallic acid, a substrate for the antioxidant propyl gallate production and trimethoprim synthesis $[6$, 7].

\footnotetext{
*Correspondence: myke_1380@hotmail.com; cristobal.aguilar@uadec. edu.mx

${ }_{1}^{1}$ Group of Bioprocesses, Food Research Department, School of Chemistry, Universidad Autónoma de Coahuila, 25280 Saltillo, Coahuila, Mexico

${ }^{2}$ Department of Food Science and Food Technology, Universidad Autónoma Agraria Antonio Narro, 25315 Saltillo, Coahuila, Mexico Full list of author information is available at the end of the article
}

The worldwide annual demand of gallic acid is 8000 tonnes approximately [8] and the natural occurrence is restricted. Nowadays, gallic acid is industrially produced by acid hydrolysis of natural occurring gallotanins. Due to the high costs, low yield of desired product and production of large toxic effluent by acid hydrolysis, an enzyme based eco-friendly technology for gallic acid production is urgently required. Microorganisms are an alternative to the gallic acid production; because they have the ability to degrade tannic acid by producing tannase [9-11].

Most of the reported tannase producing microorganisms are fungi [1], such as Aspergilii, Penicilii, Fusaria, and Trichoderma [12]. For industrial purposes, a major problem in the utilization of fungal strains is their degradation rate is relatively slow [13]. In case of bacteria, few strains are known to be tannase producer. The tannase producing bacteria include certain species of Bacillus, Corynebacterium sp., Lactobacillus sp., Serratia sp. [14], Enterococcus [15], Streptococcus [16], Pseudomonas 
[17]. In this context, literature reports related to tannase production by bacteria is limited in comparison to fungal tannase; therefore the development of studies for tannase production and gallic acid synthesis is crucial to diminish production costs. The aim of the present work was to produce tannase enzyme under anaerobic conditions by two recently isolated bacilli strains. Also, the bioconversion of tannic acid to gallic acid by the enzyme produced was evaluated.

\section{Results and discussion}

\section{Microorganism identification}

Many microorganisms, including bacteria as Lactobacillus plantarum [14], fungi such as Aspergillus niger [2], and yeast as Candida sp. [4], have been reported as tannase producers. Extensive screening studies have been conducted to find potent cultures with high tannase production capacity. In this study two bacterial strains were used to analyze their capability to produce extracellular tannase. PCR was used to amplify the $16 \mathrm{~S}$ rRNA gene from both bacterial genomes. However, the rpoB gene was amplified only from the AM1 strain. This is due to rpoB gene is amplified from the Bacilli genus. Figure 1 shows the Neighbor-Joining analysis for both bacteria. In the phylogram for Bacillus species (Fig. 1a) it was observed that AM1 strain was clustered with Bacillus
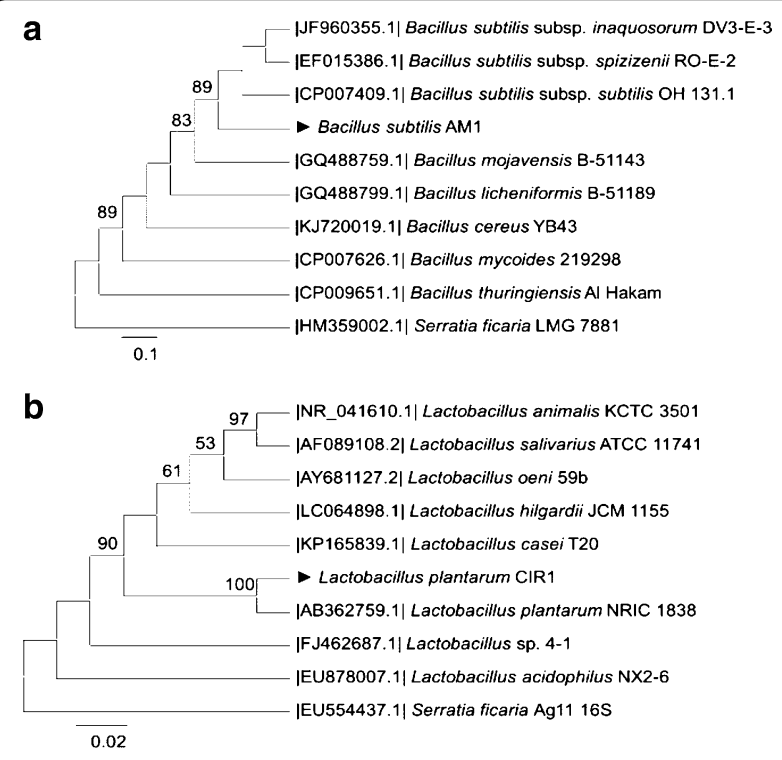

Fig. 1 Neighbor-Joining consensus tree of a Bacillus subtilis AM1 and b Lactobacillus plantarum CIR1. The identification was based on the RNA polymerase subunit beta (rpoß) gene for B. subtilis AM1 and the 16S RNA gene for Lactobacillus plantarum CIR1. The numbers over branches represent bootstrap confidence values (\%) based on 1000 replicates. Values below $50 \%$ are not shown. The scale bar denotes the nucleotide substitutions per sequence. The Genbank accessions are shown in parenthesis subtilis species and showed an $89 \%$ of identity to the three tested Bacillus subtilis strains. Figure $1 \mathrm{~b}$ shows the phylogram for the CIR1 strain. Clearly, it can be noted that CIR1 strain was closely related to Lactobacillus plantarum NRIC 1838 (100 \% of identity) and formed a separated clade. Both strains were compared with Serratia ficaria strains in order to separate the clade and demonstrate the genetic differences among species despite being the same compared gene. The taninolitic bacteria were identified as Bacillus subtillis AM1 and Lactobacillus plantarum CIR1, according to the rpoB and $16 \mathrm{~S}$ rRNA gene comparison at NCBI and the comparison by the Neighbor-Joining analysis. Bacillus subtilis and Lactobacillus plantarum strains both have been reported as tannase producer $[14,18,19,20,21,22]$. However, there are scarce reports related to the anaerobic production of tannase and gallic acid biosynthesis by microorganisms.

\section{Batch fermentation and production of tannase}

The kinetic production of tannase by the strain L. plantarum CIR1 showed that the microorganism starts its growth exponential phase after $12 \mathrm{~h}$ of fermentation, while the maximum growth was at $28 \mathrm{~h}$ of fermentation (Fig. 2). According to this figure, a fast growth of the strain CIR1 was observed, indicating that the bacteria was metabolizing tannic acid for growth and synthesis of tannase. However, a slight diminution in growth-rate was observed at $18 \mathrm{~h}$ of fermentation, being this effect directly associated with a decrease in the enzyme activity. The



Fig. 2 Batch fermentation by L. plantarum CIR1. Profile of tannase activity (open circle) and cell concentration (filled square) 
tannase activity started at $12 \mathrm{~h}$ of fermentation obtaining the maximum (1239 U/L) at $36 \mathrm{~h}$. Many authors have reported tannase titres higher than $5000 \mathrm{U} / \mathrm{L}$ for $L$. plantarum [18-21], however they used agitation speed on the batch and higher volumes that can induce stress in the microorganism to increase tannase activity.

Tannase activity for $B$. subtilis AM1 was initially detected at $12 \mathrm{~h}$ of fermentation (Fig. 3) and reached a peak at $32 \mathrm{~h}(1400 \mathrm{U} / \mathrm{L})$. Few works employing bacilli strains to produce tannase have been reported [12, 23, 24]. Results on tannase activity by Bacillus strains are contrasting. In the present work, a considerable activity of tannase was obtained from $B$. subtilis AM1 compared with the tannase activity $(362 \mathrm{U} / \mathrm{L})$ of $B$. licheniformis KBR6 [23] but, was lower than the reported for B. subtilis PAB2 (10,690 U/L) [22]. The highest production of bacterial tannase has been reported on B. sphaericus $(16,540$ $\mathrm{U} / \mathrm{L})[12]$.

Microorganism exponential growth was observed between 12 and $16 \mathrm{~h}$ of culture, while the maximum growth was reached at $28 \mathrm{~h}$ decreasing after that time. Retardation in anaerobic growth of $B$. subtilis was observed by Hoffman et al. [25]. They conclude that anaerobic conditions caused that adaptation phases has an unpredictable duration.

Growth studies on $25 \mathrm{~mL}$ flask and anaerobic conditions for both strains, indicated that the production of extracellular tannase reached the maximum production peak after the late stationary phase, contrary to many

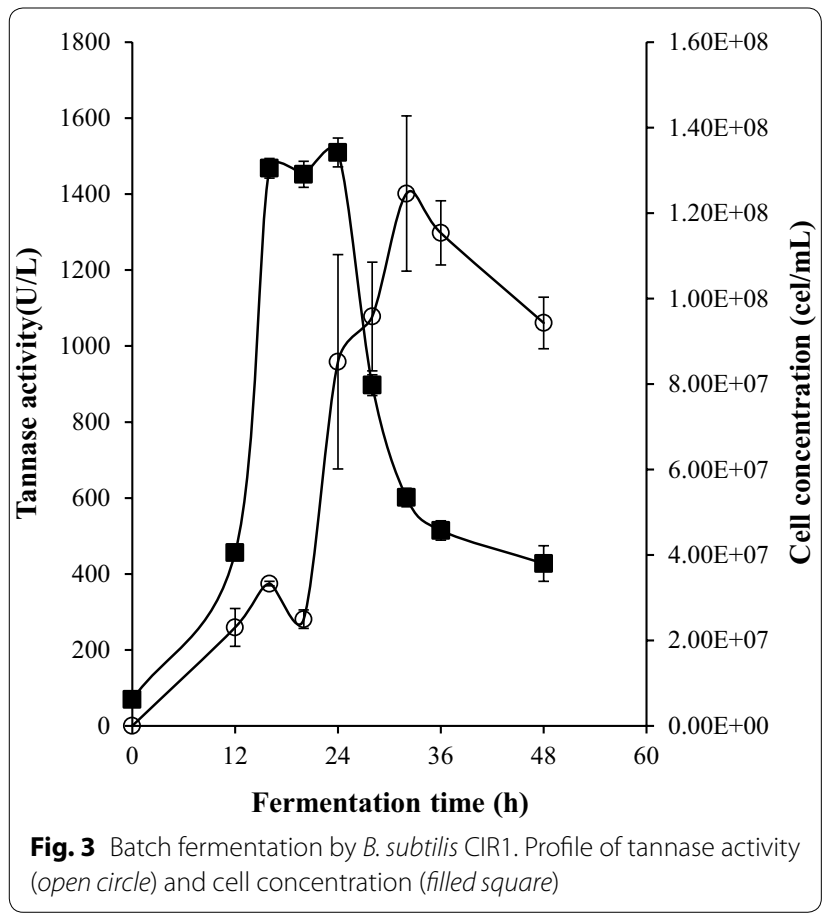

reports of maximum production in that was observed in the exponential phase of growth [12, 19]. Mondal et al. [26] reported that the maximum production of extracellular tannase occurred at the stationary phase in Bacillus cereus. Similar pattern was observed in Serratia ficaria intracellular tannase, which reaches the maximum tannase production in the late stationary phase [27].

The better adaptation of AM1 strain to the growing conditions was reflected in high productivity enzyme. Tannase productivity for $B$. subtilis AM1was $43.80 \mathrm{U} / \mathrm{L} / \mathrm{h}$ and are 1.3 fold-higher than the enzyme productivity of L. plantarum CIR1. Despite of Lactobacillus sp. has been the most reported bacterial tannase-producer strain [11], in literature the higher values of tannase productivity were obtained using Bacillus sphaericus [11] and Bacillus subtilis [22]. However, Lactobacillus sp. have potential applications in degradation of food tannins [28].

\section{Bioconversion of tannic acid to gallic acid}

Bioconversion profile from tannic acid to gallic acid for both strains is shown in Figs. 4 and 5. High concentration of substrate was consumed by the two strains in the first $12 \mathrm{~h}$ of growth while at the same time the maximum gallic acid production was 2.416 and $2.373 \mathrm{~g} / \mathrm{L}$ of medium for B. subtilis AM1 and L. plantarum CIR1 respectively. The bioconversion for both strains are lower compared






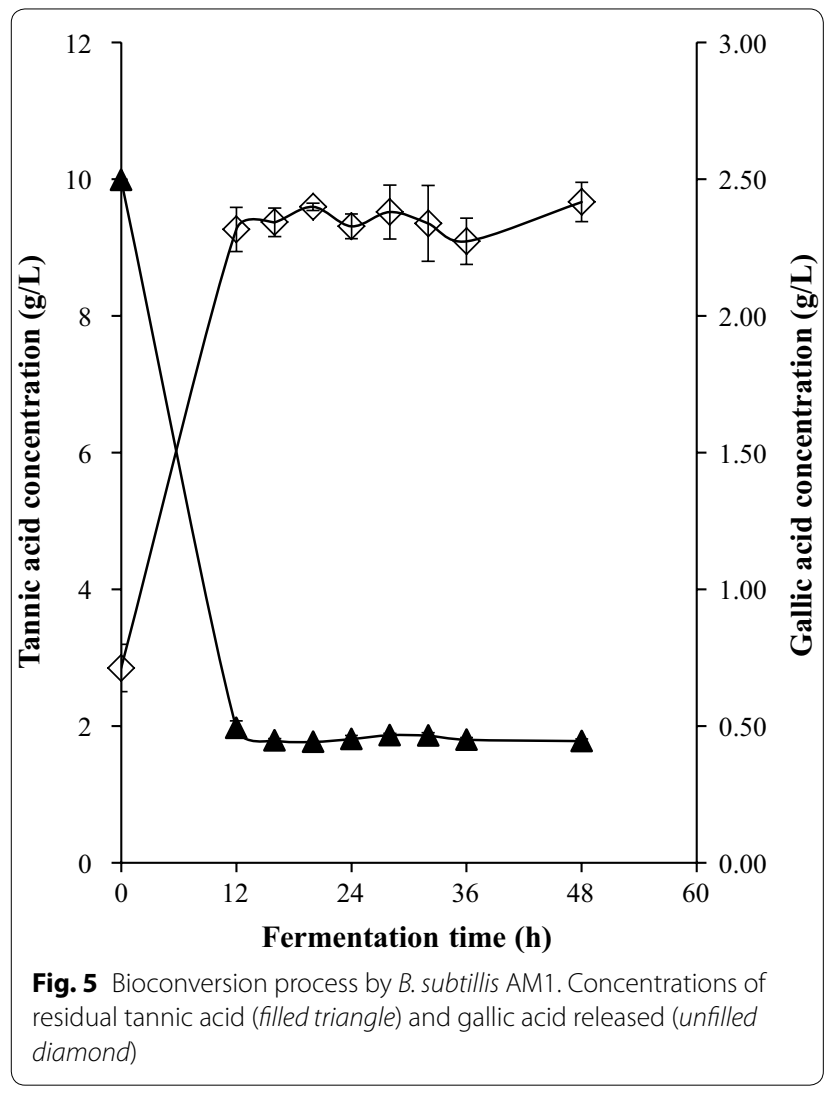

with similar reports in literature, however, conditions were different. In a previous work related to L. plantarum CIR1 the maximal productivity of gallic acid was $8.63 \mathrm{~g} / \mathrm{L}$ after $24 \mathrm{~h}$ of culture using a gas-lift bioreactor and optimized culture conditions [18]. Jana et al. [22] reported the releasing of $6.45 \mathrm{~g} / \mathrm{L}$ of gallic acid by B. subtilis PAB2 at $36 \mathrm{~h}$ of culture by optimizing the culture media.

Gallic acid synthesis keeps constant along fermentation. According to reports, it could be possible due to the enzyme gallic acid decarboxylase is not present [29]. This enzyme is used for the production of pyrogallol from gallic acid and has been reported in bacterial strains [30, 31]. The activity of gallic acid decarboxylase is limited by the presence of oxygen [32]. However, in the present work anaerobic conditions were used and the content of gallic acid showed no differences along fermentation time (Figs. 4, 5).

\section{HPLC analysis}

It is well known that HPLC analysis is very efficient in demonstrating differences in chemical constituents of samples. Figure 6 show the different peaks identified by the HPLC analysis at the $0 \mathrm{~h}$ and at the $48 \mathrm{~h}$ of fermentation in both strains. Tannic acid peak were identified at the retention time of $15.69 \mathrm{~min}$, while the gallic acid

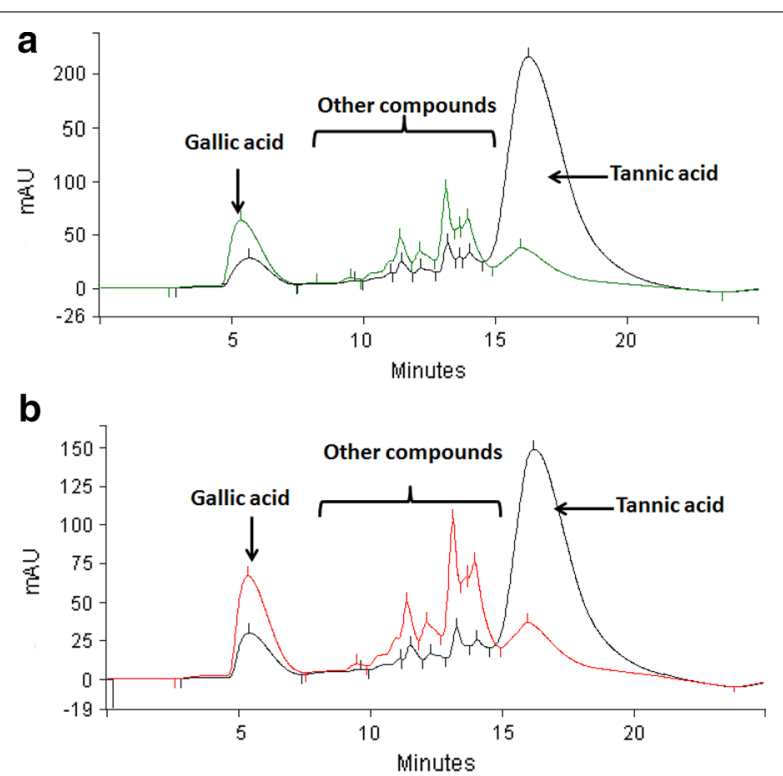

Fig. 6 HPLC chromatograms for tannic acid hydrolysis. a L. plantarum CIR1 and $\mathbf{b}$ B. subtilis AM1

peak at $6.40 \mathrm{~min}$. The hydrolysis of tannic acid and the accumulation of gallic acid can be identified clearly. Formation of gallic acid at $0 \mathrm{~h}$ of fermentation indicates the substrate hydrolysis degree [33]. Presence of this compound was confirmed by an external standard (SigmaAldrich, MO, USA) in order to compare the retention time and to know the product accumulation.

In the present work, HPLC analysis revealed the formation of different peaks with different chemical intensity along the fermentation, between the retention time of 9 and 14 min (Fig. 6). These peaks could be compounds synthesized during fermentation such as di- or tri-galoyl glucose [33-35] and could be formed because of production of tannase under anaerobic stress. Hence, probably bacteria could hydrolyze that compounds after use the available carbon source producing tannase and synthesizing gallic acid.

\section{Conclusions}

Tannase production by two bacterial strains were evaluated. Both strains have the capability to produce high titres of extracellular tannase under anaerobic conditions. Tannase production of B. subtilis AM1 was 1400 $\mathrm{U} / \mathrm{L}$, while for $L$. plantarum CIR1 was $1239 \mathrm{U} / \mathrm{L}$ after 32 and 36 h respectively. High concentrations of gallic acid were obtained. B. subtilis AM1 has the capability to release $2.416 \mathrm{~g} / \mathrm{L}$ and L. plantarum CIR1 $2.373 \mathrm{~g} / \mathrm{L}$ of gallic acid. Two compounds different to gallic acid were released during the fermentation process and were identified in the HPLC analysis as two unknown peaks that 
could be di- or tri-galoyl glucose resulted from the partial hydrolysis of tannic acid by the action of tannase.

\section{Methods}

\section{Microorganism and inoculum preparation}

Two bacterial strains were obtained from the microbial collection of the Chemical Engineering Department, University of Coahuila, and were identified as AM1 and CIR1. Both strains were maintained at $35{ }^{\circ} \mathrm{C}$, during $48 \mathrm{~h}$, using own elaborate MRS agar (Man-RogosaSharpe) containing $(\mathrm{g} / \mathrm{L})$ : beef extract, 5; peptone, 10; yeast extract, 5; dextrose, 20; $\mathrm{K}_{2} \mathrm{HPO}_{4}$, 2; sodium citrate, 2; sodium acetate, $5 ; \mathrm{MgSO}_{4} \cdot 7 \mathrm{H}_{2} \mathrm{O}, 0.1$; agar, 1.2 ; and Tween 80,1 . Inoculum was prepared by propagating the cryo-preserved strains in $20 \mathrm{~mL}$ sterile seed medium (composition same as maintenance medium excluding agar) in $25 \mathrm{~mL}$ flask for $24 \mathrm{~h}$ at $35{ }^{\circ} \mathrm{C}$ (Fisher Isotemp ${ }^{\circledR}$ Incubator Senior Model, USA) under anaerobic conditions. Incubation was carried out at $35^{\circ} \mathrm{C}$ for $48 \mathrm{~h}$.

\section{Identification of microorganisms}

Identification was carried out on the basis of the $16 \mathrm{~S}$ rRNA [36] and the gene rрoB [37] using the primers forward (16SF 5'-AGGAGGTGATCCAACCGCA-3'; rpoB 5' -tcgtattctaaccatgcgcc- $3^{\prime}$ ) and reverse (16SR $5^{\prime}$-AACTGG AGGAAGGTGGGGAT-3'; rpoB 5'-GCGAAGTGTTAG AATTACC- $3^{\prime}$ ). The amplification was carried out in a thermal cycler with $30 \mu \mathrm{L}$ volume containing $3 \mu \mathrm{L}$ of $10 \times$ buffer, $10 \mathrm{mM}$ of each dNTP, $2.4 \mu \mathrm{L}$ each primer, 5 $\mathrm{U} / \mu \mathrm{L}$ of Taq DNA polymerase and 80-100 ng of cDNA. Genomic DNA was isolated and quantified by standard methods using spectrophotometer Epoch Microplate Spectrophotometer $^{\mathrm{TM}}$ (BioTek Instrument, Winooski, Vermont, USA). The PCR was performed in a $\mathrm{P} \times 2$ Thermal Cycler (Thermo Electron Corporation, California, USA) with the following constituents in a program covering initial denaturation at $95^{\circ} \mathrm{C}$ for $5 \mathrm{~min}$; followed by 35 cycles of 1 min each at $95^{\circ} \mathrm{C}$ (denaturation), $53^{\circ} \mathrm{C}(r p o B)$ or $54{ }^{\circ} \mathrm{C}(16 \mathrm{~S})$ (alignment) and $72{ }^{\circ} \mathrm{C}$ (elongation); then an extension temperature $\left(5 \mathrm{~min}\right.$ at $\left.72{ }^{\circ} \mathrm{C}\right)$ was programmed; finally the reaction was stopped at $4{ }^{\circ} \mathrm{C}$. PCR products were electrophoresed in $1.5 \%$ agarose gel, purified (Kit Wizard $^{\circledR}$ SV Gel and PCR Clean-up System, USA) and subjected to sequencing reaction. The sequence obtained was characterized by BLAST at NCBI to find out homologues with the sequences already available. The sequences were aligned using MAFFT V6 online server (http://mafft.cbrc.jp/alingment). Phylogenetic and molecular evolutionary analysis were conducted using MEGA version 6 [38] by neighbor-joining analysis of Kimura-2 parameter distance estimates. The robustness of the tree was determined by bootstrap analysis (1000 replicates).

\section{Batch fermentation}

Fermentation was conducted in $25 \mathrm{~mL}$ anaerobic flasks containing $20 \mathrm{~mL}$ of modified medium Czapek-Dox composed of $(\mathrm{g} / \mathrm{L}): \mathrm{FeSO}_{4} \cdot 7 \mathrm{H}_{2} \mathrm{O}, 0.01 ; \mathrm{NaNO}_{3}, 3 ; \mathrm{K}_{2} \mathrm{HPO}_{4}, 1$; $\mathrm{MgSO}_{4} \cdot 7 \mathrm{H}_{2} \mathrm{O}, 0.5 ; \mathrm{KCl}, 0.5$; and tannic acid $1 \%$. The production medium was adjusted to the initial $\mathrm{pH}$ of 6 using $1 \mathrm{M} \mathrm{NaOH}$ or $1 \mathrm{~N} \mathrm{HCl}$ and sterilized $\left(121^{\circ} \mathrm{C}\right.$ for $\left.15 \mathrm{~min}\right)$. Culture medium was inoculated using $1 \%$ of inoculum and the anaerobic condition was given using nitrogen to replace the oxygen. The flasks were incubated at $30^{\circ} \mathrm{C}$ for the fermentation period of $48 \mathrm{~h}$. Samples were withdrawn at $4 \mathrm{~h}$ interval after the first $12 \mathrm{~h}$ of fermentation when tannase activity started. The cells produced were counted using a Neubauer chamber. Then the cells were separated from the medium by centrifugation at $10,000 \mathrm{rpm}$ for $15 \mathrm{~min}$. The clarified supernatant was used for the analysis of tannase activity, gallic acid synthesis and tannic acid degradation.

\section{Tannase activity assay}

The tannase activity was evaluated by a spectrophotometric method [39]. The method is based on the formation of chromogen between gallic acid (released by the action of tannase on methyl gallate) and rhodanine (2-thio-4-ketothiazolidine). For determine the tannase activity 4 solutions were prepared: citrate buffer $(50 \mathrm{mM}$, $\mathrm{pH} 5)$, methyl gallate $(0.01 \mathrm{M}$ in citrate buffer $50 \mathrm{mM}$, $\mathrm{pH} 5)$, rhodanine $(0.667 \% \mathrm{w} / \mathrm{v}$ in methanol) and $\mathrm{KOH}$ $(0.5 \mathrm{~N})$. Tannase assay procedure includes the addition of $0.25 \mathrm{~mL}$ of crude enzyme to the same volume of methyl gallate. This was followed by the addition of $0.30 \mathrm{~mL}$ of rhodanine and $0.20 \mathrm{~mL}$ of potassium hydroxide solution with incubation at $30{ }^{\circ} \mathrm{C}$ for $5 \mathrm{~min}$ after each addition. Reaction was diluted with $4 \mathrm{~mL}$ of distilled water and again incubated at $30{ }^{\circ} \mathrm{C}$ for $10 \mathrm{~min}$. The color formation was read at $520 \mathrm{~nm}$ using a spectrophotometer VELAB VE-5600UV (D.F., México). Tubes for blank and control were used simultaneously for each sample. One unit of tannase was defined as the amount of enzyme able to release one $\mu \mathrm{mol}$ of gallic acid formed per minute under assay conditions (temperature and time).

\section{HPLC analysis of gallic acid synthesis and substrate degradation}

HPLC analysis was carried out according to ChávezGonzález et al. [33]. The clarified supernatant was filtered through a $0.45 \mu \mathrm{m}$ membrane and subjected to analysis on an HPLC system (Varian ProStar 3300, Varian, USA) with a Star800 Photo Diode Array detector. Separation was carried out using an Octadecylsilane column (Pursuit XRs $5 \mathrm{C} 185 \mu \mathrm{m} \times 150 \mathrm{~mm} \times 4.6 \mathrm{~mm}$ ) and a mobile three-phase gradient system [A: methanol, B: acetonitrile, C: acetic acid (3\%)] at room temperature and a flow 
rate of $1 \mathrm{~mL} \mathrm{~min}^{-1}$ with an injection volume of $10 \mu \mathrm{L}$. Detection was carried out at $280 \mathrm{~nm}$. Standard solutions $(10 \mathrm{~g} / \mathrm{L})$ of tannic acid and gallic acid (Sigma-Aldrich, USA) were analyzed to compare the results.

\section{Statistical analysis}

All experimental data were carried out in triplicate, mean values and standard deviations were calculated. Software Microsoft Excel 2007 (Microsoft Corporation, Redmond, WA, USA) was used to plot the experimental data.

\section{Authors' contributions}

PAZ contributed to the work generating the data and writing the paper. MAC is the intellectual author of the work. JM and RRH provided the lab resources for the batch fermentation and strains identification. JEWP and REB collaborate with the HPLC data analysis and read the proof manuscript. CNA is the leader of the group and led the work. All authors read and approved the final manuscript.

\section{Author details}

${ }^{1}$ Group of Bioprocesses, Food Research Department, School of Chemistry, Universidad Autónoma de Coahuila, 25280 Saltillo, Coahuila, Mexico. ${ }^{2}$ Department of Food Science and Food Technology, Universidad Autónoma Agraria Antonio Narro, 25315 Saltillo, Coahuila, Mexico.

\section{Acknowledgements}

Author Pedro Aguilar-Zárate acknowledge the postgraduate scholarship provided by the Mexican Council for Science and Technology (CONACYT).

\section{Competing interests}

The authors declare that they have no competing interests.

Received: 25 May 2015 Accepted: 24 November 2015

Published online: 30 December 2015

\section{References}

1. Aguilar CN, Rodríguez R, Gutiérrez-Sánchez G, Augur C, Favela-Torres E, Prado-Barragan LA, Ramírez-Coronel A, Contreras-Esquivel JC. Microbial tannases: advances and perspectives. Appl Microbiol Biotechnol. 2007;76:47-59.

2. Aguilar CN, Augur C, Favela-Torres E, Viniegra-González G. Induction and repression patterns of fungal tannase in solid-state and submerged cultures. Proc Biochem. 2001:36:565-70.

3. Rodriguez-Duran LV, Valdivia-Urdiales B, Contreras-Esquivel JC, RodriguezHerrera R, Aguilar CN. Novel strategies for upstream and downstream processing of tannin acyl hydrolase. Enzyme Res. 2011;2011:823619.

4. Belmares R, Contreras-Esquivel JC, Rodríguez-Herrera R, Coronel AR, Aguilar CN. Microbial production of tannase: an enzyme with potential use in food industry. LWT-Food Sci Technol. 2004;37:857-64

5. García-Conesa M-T, Østergaard P, Kauppinen S, Williamson G. Hydrolysis of diethyl diferulates by a tannase from Aspergillus oryzae. Carbohydr Polym. 2001;44:319-24.

6. Kar B, Banerjee R, Bhattacharyya BC. Optimization of physicochemical parameters for gallic acid production by evolutionary operation-factorial design technique. Proc Biochem. 2002;37:1395-401.

7. Lu M-J, Chen C. Enzymatic modification by tannase increases the antioxidant activity of green tea. Food Res Int. 2008;41:130-7.

8. Lokeswari N. Production of gallic acid using mutant strain of Aspergillus oryzae. J Pharm Res. 2010;3:1402-6.

9. Banerjee D, Pati BR. Optimization of tannase production by Aureobasidium pullulans DBS66. J Microbiol Biotechnol. 2007;17:1049-53.

10. Bajpai B, Patil S. Tannin acyl hydrolase (EC 3.1. 1.20) activity of Aspergillus, Penicillium, Fusarium and Trichoderma. World J Microbiol Biotechnol. 1996;12:217-20
11. Aguilar-Zárate P, Cruz-Hernández M, Montañez J, Belmares-Cerda R, Aguilar C. Bacterial tannases: production, properties and applications. Rev Mex Ing Quím. 2014;13:63-74.

12. Raghuwanshi S, Dutt K, Gupta P, Misra S, Saxena RK. Bacillus sphaericus: The highest bacterial tannase producer with potential for gallic acid synthesis. J Biosci Bioeng. 2011;111:635-40.

13. Selwal MK, Yadav A, Selwal KK, Aggarwal N, Gupta R, Gautam S. Optimization of cultural conditions for tannase production by Pseudomonas aeruginosa IIIB 8914 under submerged fermentation. World J Microbiol Biotechnol. 2010;26:599-605.

14. Rodríguez H, de las Rivas B, Gómez-Cordovés C, Muñoz R. Characterization of tannase activity in cell-free extracts of Lactobacillus plantarum CECT 748. Int J Food Microbiol. 2008;121:92-8.

15. Goel G, Puniya AK, Aguilar CN, Singh K. Interaction of gut microflora with tannins in feeds. Naturwissenchaften. 2005;92:503-947.

16. Jimenez N, Reverón I, Esteban-Torres M, de Felipe FL, de las Rivas B, Muñoz R. Genetic and biochemical approaches towards unravelling the degradation of gallotannins by Streptococcus gallolyticus. Microb Cell Fact. 2014;13:1-11.

17. Selwal MK, Yadav A, Selwal KK, Aggarwal NK, Gupta R, Gautam SK. Optimization of cultural conditions for tannase production by Pseudomonas aeruginosa IIIB 8914 under submerged fermentation. World J Microbiol Biotechnol. 2010;26:599-605.

18. Aguilar-Zarate P, Cruz-Hernandez MA, Montanez JC, Belmares-Cerda RE, Aguilar CN. Enhancement of tannase production by Lactobacillus plantarum CIR1: validation in gas-lift bioreactor. Bioproc Biosyst Eng. 2014;37:2305-16

19. Kannan N, Aravindan R, Viruthagiri T. Effect of culture conditions and kinetic studies on extracellular tannase production by Lactobacillus plantarum MTCC 1407. Indian J Biotechnol. 2011;10:321-8.

20. Natarajan K, Rajendran A. Effect of fermentation parameters on extra cellular tannase production by Lactobacillus plantarum MTCC 1407. J Chem. 2009;6:979-84.

21. Ayed L, Hamdi M. Culture conditions of tannase production by Lactobacillus plantarum. Biotechnol Lett. 2002;24:1763-5.

22. Jana A, Maity C, Hakder SK, Mondal KC, Pati BR, Mohapatra PKD. Enhanced tannase production by Bacillus subtilis PAB2 with concomitant antioxidant production. Biocatal Agric Biotechnol. 2013;2:363-71.

23. Das Mohapatra P, Maity C, Rao R, Pati B, Mondal K. Tannase production by Bacillus licheniformis KBR6: Optimization of submerged culture conditions by Taguchi DOE methodology. Food Res Int. 2009;42:430-5.

24. Mondal K, Pati B. Studies on the extracellular tannase from newly isolated Bacillus licheniformis KBR 6. J Basic Microbiol. 2000;40:223-32.

25. Hoffmann T, Troup B, Szabo A, Hungerer C, Jahn D. The anaerobic life of Bacillus subtilis: cloning of the genes encoding the respiratory nitrate reductase system. FEMS Microbiol Lett. 1995;131:219-25.

26. Mondal KC, Banerjee D, Banerjee R, Pati BR. Production and characterization of tannase from Bacillus cereus KBR9. J Gen Appl Microbiol. 2001:47:263-7.

27. Belur PD, Gopal M, Nirmala K, Basavaraj N. Production of novel cellassociated tannase from newly isolated Serratia ficaria DTC. J Microbiol Biotechnol. 2010;20:732-6.

28. Curiel JA, Rodríguez H, Landete JM, de las Rivas B, Muñoz R. Ability of Lactobacillus brevis strains to degrade food phenolic acids. Food Chem. 2010:120:225-9.

29. Mingshu L, Kai Y, Qiang H, Dongying J. Biodegradation of gallotannins and ellagitannins. J Basic Microbiol. 2006;46:68-84.

30. Kumar RA, Jayaraman A, Lakshmanan M, Gunasekaran P. Bioconversion of gallic acid into pyrogallol by immobilized Citrobacter freundii TB3. J Ferment Bioeng. 1992;74:159-62.

31. Zeida M, Wieser M, Yoshida T, Sugio T, Nagasawa T. Purification and characterization of gallic acid decarboxylase from Pantoea agglomerans T71. Appl Environ Microbiol. 1998;64:4743-7.

32. Brune A, Schink B. Phloroglucinol pathway in the strictly anaerobic Pelobacter acidigallici: fermentation of thrihydroxybenzenes to acetate via triacetic acid. Arch Microbiol. 1992;157:417-24.

33. Chávez-González ML, Contreras-Esquivel JC, Prado-Barragán LA, Rodríguez R, Aguilera-Carbo AF, Rodríguez LV, Aguilar CN. Microbial and enzymatic hydrolysis of tannic acid: influence of substrate chemical quality. Chem Pap. 2012;66:171-7. 
34. Salminen J-P, Ossipov V, Loponen J, Haukioja E, Pihlaja K. Characterisation of hydrolysable tannins from leaves of Betula pubescens by high-performance liquid chromatography-mass spectrometry. J Chromatogr A. 1999:864:283-91.

35. Beasley TH, Ziegler HW, Bell AD. Determination and characterization of gallotannin by high performance liquid chromatography. Anal Chem. 1977;49:238-43.

36. Guillén-Cruz R, Hernández-Castillo FD, Gallegos-Morales G, RodríguezHerrera R, Aguilar-González C, Padrón-Corral E, Reyes-Valdés H. Bacillus spp. como biocontrol en un suelo infestado con Fusarium spp., Rhizoctonia solani Kühn y Phytophthora capsici Leonian y su efecto en el desarrollo y rendimiento del cultivo de chile (Capsicum annum L.). Rev Mex Fitopatol. 2006;24:105-14
37. Meintanis C, Chalkou K, Kormas KA, Lymperopoulou D, Katsifas E, Hatzinikolaou D, Karagouni A. Application of rpoB sequence similarity analysis, REP-PCR and BOX-PCR for the differentiation of species within the genus Geobacillus. Lett Appl Microbiol. 2008;46:395-401.

38. Tamura K, Stecher G, Peterson D, Filipski A, Kumar S. MEGA6: mMolecular evolutionary genetics analysis version 6.0. Mol Biol Evol. 2013;30:2725s-9s.

39. Sharma S, Bhat T, Dawra R. A spectrophotometric method for assay of tannase using rhodanine. Anal Biochem. 2000;279:85-9.
Submit your next manuscript to BioMed Central and we will help you at every step:

- We accept pre-submission inquiries

- Our selector tool helps you to find the most relevant journal

- We provide round the clock customer support

- Convenient online submission

- Thorough peer review

- Inclusion in PubMed and all major indexing services

- Maximum visibility for your research

Submit your manuscript at www.biomedcentral.com/submit
(O) BioMed Central 